\title{
Evidence that Protein Constituents of Postsynaptic Membrane Specializations Are Locally Synthesized: Analysis of Proteins Synthesized within Synaptosomes
}

\author{
Anuradha Rao and Oswald Steward \\ Department of Neuroscience and the Neuroscience Graduate Program, University of Virginia, Charlottesville, Virginia \\ 22908
}

Previous studies have led to the hypothesis that some proteins of the postsynaptic membrane are locally synthesized at postsynaptic sites. To evaluate this hypothesis, synaptosome fractions that included fragments of dendrites were allowed to incorporate labeled amino acid into protein. The labeled synaptosomes were then subfractionated to the level of the synaptic plasma membrane (SPM) and then the synaptic junctional complex (SJC). The specific activity (cpm/ $\mu \mathrm{g}$ protein) of the synaptosome fraction and its subfractions was assessed by scintillation counting and protein assay, and labeled polypeptides were characterized by SDS-PAGE and fluorography. The contribution of mitochondrial and eucaryotic protein synthesis to the overall incorporation was evaluated using cycloheximide (CYC), a eucaryotic protein synthesis inhibitor, and chloramphenicol (CAP), a mitochondrial protein synthesis inhibitor.

Both the SPM and the SJC subfractions obtained from labeled synaptosomes contained labeled polypeptides. The SPM from labeled synaptosomes had a specific activity approximately equal to that of other nonmitochondrial membrane components of the synaptosome. Thus, labeling of the SPM was not due to contamination by these other labeled membrane components. The mitochondrial fraction had the highest specific activity of the membrane components of the labeled synaptosome, but the specific activity was reduced by $47 \%$ in mitochondrial fractions from CAP-treated synaptosomes, while the specific activity of the SPM was not reduced by this treatment. Thus, SPM labeling is not due to mitochondrial contamination. The specific activity of the detergent-insoluble SJC was comparable to that of the SPM from which it was derived. The possibility of labeling of SPM and SJC by contamination with soluble proteins was assessed by adding labeled soluble proteins to a cold synaptosome preparation that was then subfractionated to obtain the SPM and SJC. There was no detectable binding of labeled soluble proteins to the SPM or SJC. These results support the hypothesis that some synaptic proteins are locally synthesized.

\footnotetext{
Received Dec. 31, 1990; revised Apr. 1, 1991; accepted Apr. 18, 1991.

We thank P. M. Falk for technical assistance with the electron micrography and Dr. E. R. Torre for technical advice. This work was supported by NIH Grant NS1 2333 (O.S.).

Correspondence should be addressed to Dr. Steward, Dept. of Neuroscience, University of Virginia School of Medicine, Box 230, Charlottesville, VA 22908. Copyright (C) 1991 Society for Neuroscience 0270-6474/91/112881-15\$03.00/0
}

Fluorographs of SDS gels of SPM from labeled synaptosomes revealed labeled bands at approximate molecular weights of $14,18,26,28,36,38,42,45,55,60$, and $116 \mathrm{kDa}$. Six of these labeled polypeptides at $38,42,45,55,60$, and $116 \mathrm{kDa}$ were still evident in fluorographs of the synaptic junctional complex from labeled synaptosomes. None of these labeled bands were seen in fluorographs of SPM and SJC from CYC-treated synaptosomes, whereas they were still present in fluorographs of CAP-treated synaptosomes. These labeled polypeptides are therefore produced by eucaryotic ribosomal systems. Several additional high molecular weight bands at 92,100,180, 200, and $220 \mathrm{kDa}$ and occasionally 2-3 bands between 40 and $60 \mathrm{kDa}$ were seen in similar samples treated with urea and run on urea-containing SDS gels.

There is growing evidence that some protein constituents of the synaptic junctional region may be locally synthesized near individual postsynaptic sites (for a review, see Steward et al., 1988). This hypothesis was originally based on the discovery that polyribosomes and associated membranous organelles are selectively localized beneath postsynaptic sites on neurons (Steward and Levy, 1982; Steward, 1983). Later studies revealed that polyribosomes are particularly prominent during periods of synapse growth and were closely associated with developing postsynaptic membrane specializations (Palacios-Pru et al., 1981, 1988; Steward and Falk, 1986). On the basis of these data, it was suggested that dendritic polyribosomes might synthesize some of the protein constituents of the postsynaptic membrane specialization (Palacios-Pru et al., 1981, 1988; Steward and Falk, 1986).

To test the hypothesis that proteins of the postsynaptic membrane specialization are locally synthesized, newly synthesized protein that is manufactured locally must be distinguished from newly synthesized protein supplied by the cell body. In the present study, the approach we use takes advantage of the fact that it is possible to physically separate pinched-off nerve endings with attached portions of the postsynaptic dendrite. This can be accomplished by preparing synaptosomes, which contain both pre- and postsynaptic cell fragments. Earlier studies have shown that synaptosomal fractions include polyribosome-containing cell fragments that resemble dendrites (Autilio et al., 1968; Verity et al., 1980). These fractions exhibit a protein synthetic capacity that appears to be mediated largely by eucaryotic ribosomes, in that incorporation is sensitive to eucaryotic protein synthesis inhibitors such as cycloheximide and in- 
sensitive to the mitochondrial protein synthesis inhibitor, chloramphenicol (Autilio et al., 1968; Morgan and Austin, 1968). EM autoradiographic studies after synthesis in the presence of a radiolabeled amino acid precursor have revealed that most synthesis occurred within cell fragments containing cytoplasm and ribosomes, many of which also bore the postsynaptic density (PSD) characteristic of dendrites (Cotman and Taylor, 1971; Gambetti et al., 1972). These and other observations suggested that a major part of the protein synthetic activity of synaptosomal fractions was due to a dendritic component (Verity et al., 1980). While these studies demonstrated local synthesis, they did not evaluate whether locally synthesized proteins were components of the synapse.

The present study combines the approach of using synaptosome fractions as the protein synthesizing system (to ensure that any incorporation reflects local synthesis) with further subfractionation of the synaptosomes to the level of the synaptic plasma membrane (SPM) and synaptic junctional complex (SJC) to determine whether recently synthesized proteins are components of the synaptic region. The only contiguous source of newly synthesized protein for the synaptic junction in the synaptosomal fraction is the subsynaptic polyribosome. Therefore, the appearance of newly synthesized proteins in subcellular fractions enriched in synaptic junctions after synaptosomal protein synthesis would suggest that proteins of the synaptic junction are locally synthesized by subsynaptic polyribosomes. We report here that labeled protein appears in fractions enriched in synaptic junctions after synaptosomal incorporation. This labeling was not due to contamination of the synaptic membrane fractions by nonsynaptic membranes, or the result of adventitious binding of soluble proteins to the synaptic junction. In addition, labeling in the synaptic fractions could not be accounted for by mitochondrial protein synthesis. SDS-PAGE and fluorography were used to estimate how many protein species are locally synthesized and to provide an initial characterization of their molecular weights. Some of these results have been reported in abstract form (Rao et al., 1988) and summarized in a review (Steward et al., 1988).

\section{Materials and Methods}

Synaptosome preparation. Synaptosomes were prepared from the forebrains of 7-40-d-old rat pups (6-12 pups/preparation) by the method of Verity et al. (1972, 1980) (Fig. 1A). A 20\% (w/v) homogenate was prepared from chopped forebrain $(5-10 \mathrm{gm}$, wet $w \mathrm{t})$ in $0.35 \mathrm{M}$ sucrose, $10 \mathrm{~mm}$ Tris, $0.5 \mathrm{~mm}$ EGTA solution brought to $\mathrm{pH} 7.4$ with $\mathrm{KOH}$. The homogenate was centrifuged at $2000 \times g$ for 1 min on a Beckman model $\mathrm{J}-21 \mathrm{~B}$ centrifuge using a JA-20 fixed angle rotor to remove a nuclear pellet (P1). P1 was washed once by resuspension in the homogenizing buffer and repelleting. The supernatant was combined with the supernatant from the first centrifugation, and the pellet was discarded. The pooled supernatant ( $\mathrm{S} 1)$ was centrifuged at $23,000 \times g$ for 4 min to yield a crude mitochondrial pellet $(\mathrm{P} 2)$, which was washed once by resuspension in homogenizing buffer and repelleting. The pellet was then brought up to $6 \mathrm{ml}$ total volume with the same buffer. This suspension was layered onto a discontinuous gradient of 5 and $13 \%$ Ficoll in $0.35 \mathrm{M}$ sucrose $(1 \mathrm{ml}$ suspension $/ 2 \mathrm{ml}$ each of 5 and $13 \%$ Ficoll) that had been allowed to equilibrate at $4^{\circ} \mathrm{C}$ for $1 \mathrm{hr}$ prior to loading the sample. The gradient was centrifuged at $45,000 \times g \times 45 \mathrm{~min}$ on a Beckman L5-75 ultracentrifuge using a SW 50.1 swinging bucket rotor. A synaptosomal fraction was collected from the 5-13\% interface and washed by diluting in $0.35 \mathrm{M}$ sucrose $/ 10 \mathrm{~mm}$ Tris and centrifuging at $23,000 \times g$ for $20 \mathrm{~min}$. The synaptosomal pellet was resuspended in incubation buffer, and the protein content was determined by the Bradford assay (Bradford, 1976). The synaptosomal suspension was then used for labeling and further fractionation. The synaptosome isolation procedure was carried out at $4^{\circ} \mathrm{C}$ and took approximately $2.5 \mathrm{hr}$.
Protein synthesis. Synaptosomes were incubated at $37^{\circ} \mathrm{C}$ in a Dubnoff shaker bath in the incubation buffer $(50 \mathrm{~mm} \mathrm{NaCl}, 25 \mathrm{mM} \mathrm{KCl}, 100$ mM sucrose, $33 \mathrm{~mm}$ Tris hydrochloride, $5 \mathrm{~mm} \mathrm{Na}_{2} \mathrm{HPO}_{4}, 5 \mathrm{~mm} \mathrm{MgCl}$, $\mathrm{pH}$ 7.4) at a protein concentration of $1 \mathrm{mg} / \mathrm{ml}$. Initial studies evaluated the time course of incorporation of label into protein and the extent of protein synthesis in synaptosomes prepared from rats of different ages. To analyze the time course of incorporation, synaptosomes were prepared from 16-d-old rat pups and incubated for $0,5,10,20,30,45$, and $60 \mathrm{~min}$ in buffer containing $10 \mu \mathrm{Ci} / \mathrm{ml}$ of ${ }^{3} \mathrm{H}$-leucine. The reaction was terminated by adding an equal volume of $10 \%$ trichloroacetic acid (TCA). The TCA precipitate was washed 2 times in 5\% TCA and 3 timcs in acetone, dried, and dissolved in $0.5 N$ sodium hydroxide. This sample was used for protein assay and liquid scintillation counting. To determine the extent of protein synthesis at different ages, we compared the extent of incorporation in synaptosomes prepared from $7,10,13$, $16,19,20,26,29$, and 40-d-old rat pups. Synaptosomal fractions were incubated with $10 \mu \mathrm{Ci} / \mathrm{ml}{ }^{3} \mathrm{H}$-leucine for $45 \mathrm{~min}$. The reaction was terminated by the addition of TCA, and the sample was processed as described above. Sixteen synaptosome preparations were labeled with ${ }^{3} \mathrm{H}$-leucine in this way. Five of the preparations were also examined electron microscopically to assess the composition of the fraction.

To evaluate the effects of different protein synthesis inhibitors on incorporation and to measure the specific activity of protein in different subfractions of the synaptosome, synaptosome preparations from 1326-d-old rat pups were incubated as described above with ${ }^{35} \mathrm{~S}$-methionine as the tracer $\left(200 \mu \mathrm{Ci}{ }^{35} \mathrm{~S}\right.$-methionine/ml of buffer). When protein synthesis inhibitors were used with ${ }^{35} \mathrm{~S}$-methionine, the synaptosome fractions were split, with one sample being incubated as described above, while others were incubated with $500 \mu \mathrm{g} / \mathrm{ml}$ cycloheximide (CYC), 50 $\mu \mathrm{g} / \mathrm{ml}$ chloramphenicol (CAP), or 10-50 $\mu \mathrm{g} / \mathrm{ml} \mathrm{RNase.} \mathrm{In} \mathrm{two} \mathrm{initial}$ experiments, protein synthesis was terminated by adding an equal volume of $10 \%$ TCA, and the synaptosome samples were processed as described above. When the synaptosomes were to be subfractionated after labeling, the reaction was halted by cooling on ice and pelleting the synaptosomes at $23,000 \times g \times 15 \mathrm{~min}$, after which the synaptosomes were fractionated as described below.

Two preparations were labeled without inhibitors and subfractionated, eight were labeled in the presence of one or more of the inhibitors listed above and then subfractionated, and one preparation labeled in the presence of inhibitors was subfractionated only to the level of the crude synaptosomal membrane (CSM).

Three experiments were carried out in which the labeled synaptosomes were subfractionated and all membrane and SJC samples collected were dissolved in a $4 \mathrm{~m}$ urea buffer and analyzed on urea-SDS gels. These experiments were not included in the specific activity and electron microscopic analyses but are described in the gel analyses.

Fractionation. The labeled synaptosomes were fractionated to obtain an SPM fraction and then an SJC fraction by the method of Cotman and Taylor (1972) as modified by Kelly and Cotman (1981) for young animals (Fig. $1 B$ ). Briefly, the synaptosomal pellet was resuspended in 5 volumes of $0.1 \mathrm{~mm}$ HEPES ( $\mathrm{pH} 7.5$ ) to osmotically lyse the synaptosomes. Membrane particles were pelleted by centrifugation $(23,000$ $\times g \times 15 \mathrm{~min}$ ) and washed once in $0.16 \mathrm{M}$ sucrose, $50 \mu \mathrm{M} \mathrm{CaCl}{ }_{2}$. The pellets were resuspended in $0.5 \mathrm{~mm}$ iodonitrotetrazolium violet (INT) and $20 \mathrm{~mm}$ succinate (in phosphate buffer, $\mathrm{pH} 7.6$ ) and incubated for $20 \mathrm{~min}$ at $30^{\circ} \mathrm{C}$ to increase mitochondrial bouyant density by the deposition of formazan. The reaction was terminated by centrifuging at $10,000 \times g$ for $7 \mathrm{~min}$, and the pellets were washed twice in $0.16 \mathrm{M}$ sucrose, $50 \mu \mathrm{M} \mathrm{CaCl}$. The pellets, composed of crude synaptosomal membrane, were resuspended after adding $0.8 \mathrm{ml}$ of $0.32 \mathrm{M}$ sucrose, 50 $\mu \mathrm{M} \mathrm{CaCl}_{2}$ to each pellet. One-milliliter aliquots of each suspension were layered onto discontinuous sucrose gradients $(1 \mathrm{ml}$ each of 0.8 , 1.0 , and $1.2 \mathrm{M}$ sucrose, $50 \mu \mathrm{M} \mathrm{CaCl}_{2}$ ) prepared $1 \mathrm{hr}$ previously in Beckman Ultraclear $13 \times 51-\mathrm{mm}$ centrifuge tubes. The tubes were centrifuged for $90 \mathrm{~min}$ at $75,465 \times \mathrm{g}$.

To obtain the SJC fraction, the SPM fraction was collected from the $1.0 \mathrm{M} / 1.2 \mathrm{M}$ interface, diluted with 3 volumes of $50 \mu \mathrm{M} \mathrm{CaCl}$, and pelleted. The SPM pellet was then suspended in $200-600 \mu \mathrm{l}$ of $2 \mathrm{mM}$ bicine and treated with twice its volume of Triton X-100 solution (2 $\mathrm{mm}$ bicine, $2 \mathrm{mM}$ EDTA, $0.4 \%$ Triton) for $10 \mathrm{~min}$ at room temperature. The Triton : protein ratio ranged from $2: 1$ to $40: 1$. This step solubilizes extrajunctional synaptic membranes from synaptic junctional complexes. Synaptic junctional complexes were then isolated by centrifugation at $68,000 \times g \times 60 \mathrm{~min}$ through $1.0 \mathrm{M}$ sucrose, $50 \mu \mathrm{M} \mathrm{CaCl}$, and harvested as a pellet. In three experiments, we analyzed the Triton- 
A

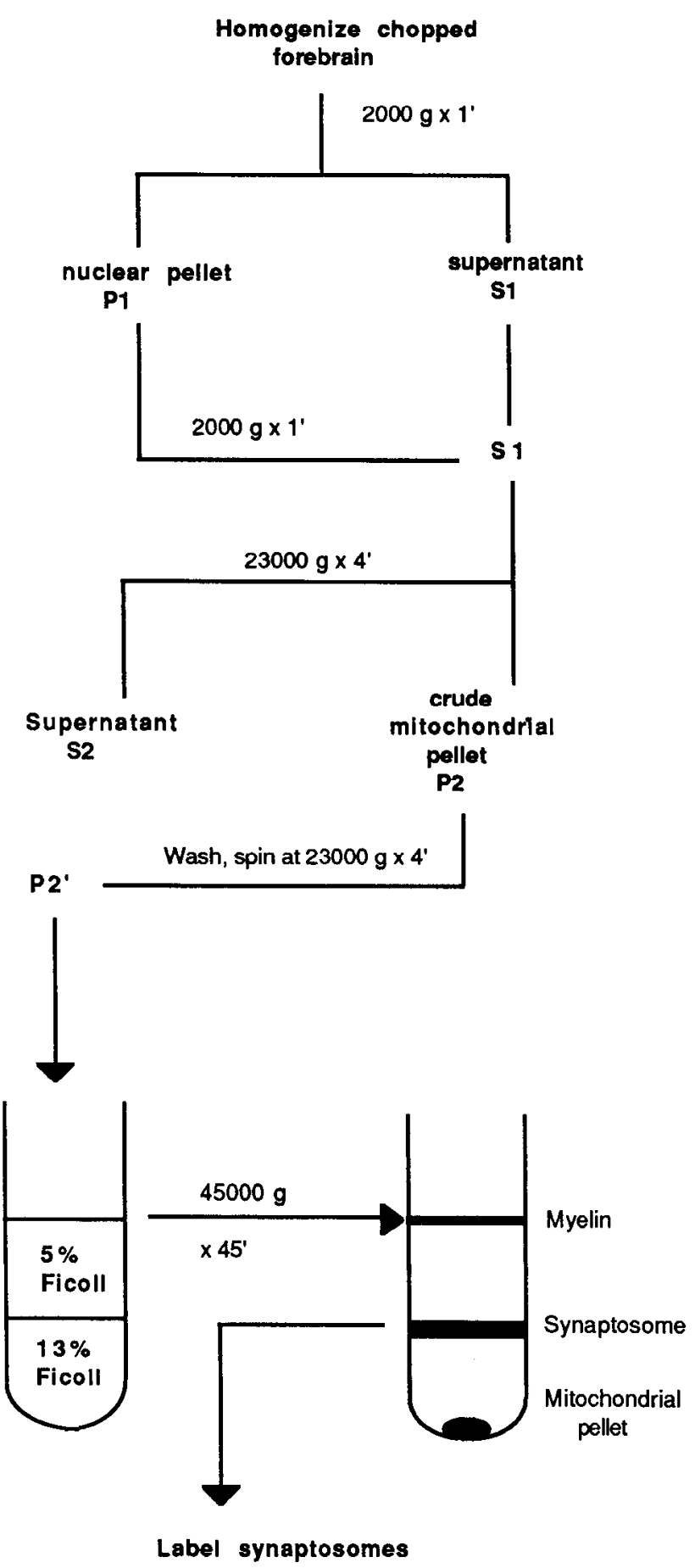

$\mathbf{B}$

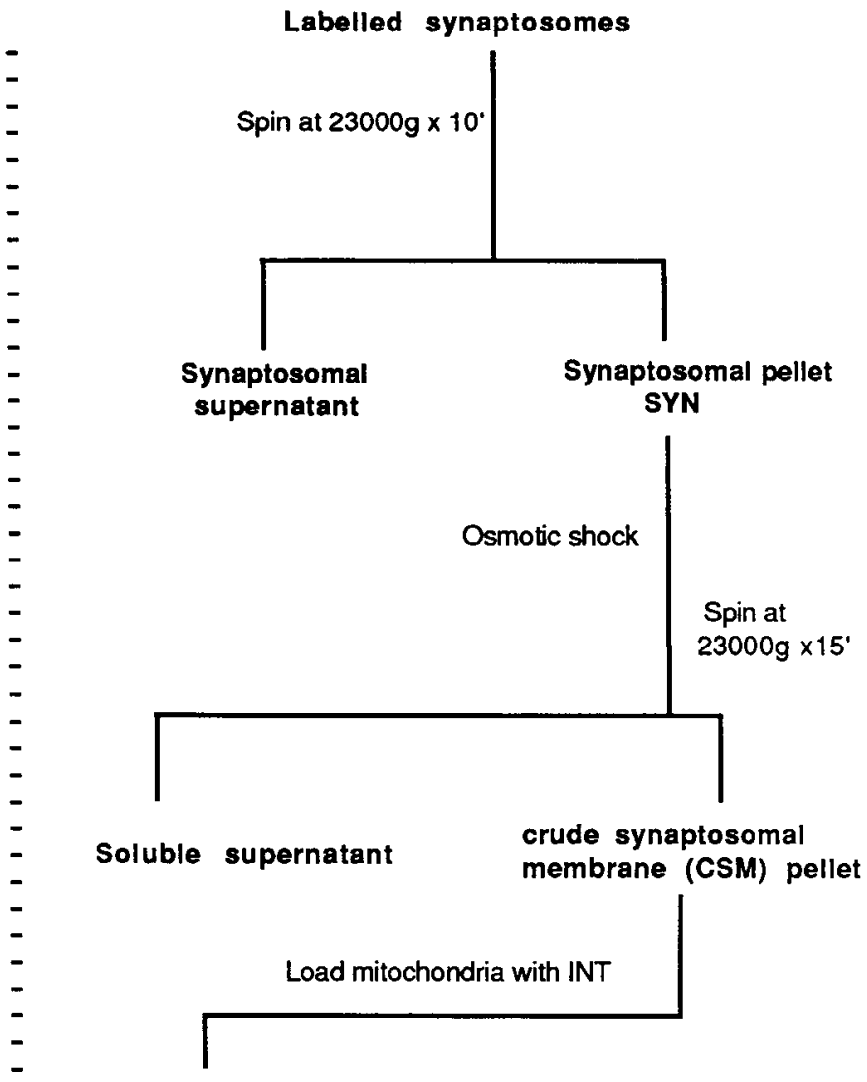

Crude synaptosomal membrane
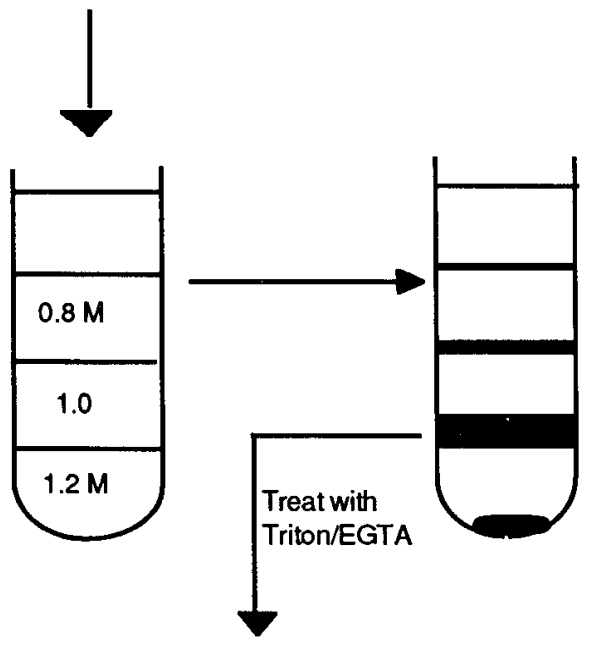

Band 1/ myelin

Band 2/ membranes

synaptic plasma membrane (SPM)

Mitochondrial pellet

Figure 1. Schematic depictions of experimental protocols. A, Preparation of synaptosomes; $B$, subfractionation of synaptosomes to SPM and SJC. INT, iodonitrotetrazolium violet.

soluble extract along with the Triton-insoluble SJC. To do this, the Triton extract was diluted with bicine buffer and then concentrated by centrifuging overnight in a Centricon 10 filter unit, which retained all proteins of molecular weight higher than $10 \mathrm{kDa}$. The concentrate was dissolved in $2 \times$ Laemmli buffer, and approximately equal protein loads from control and CYC- or CAP-treated preparations were applied to the gel along with SJC samples from the same preparation.

Electron microscopic analysis. Samples for electron microscopy were 


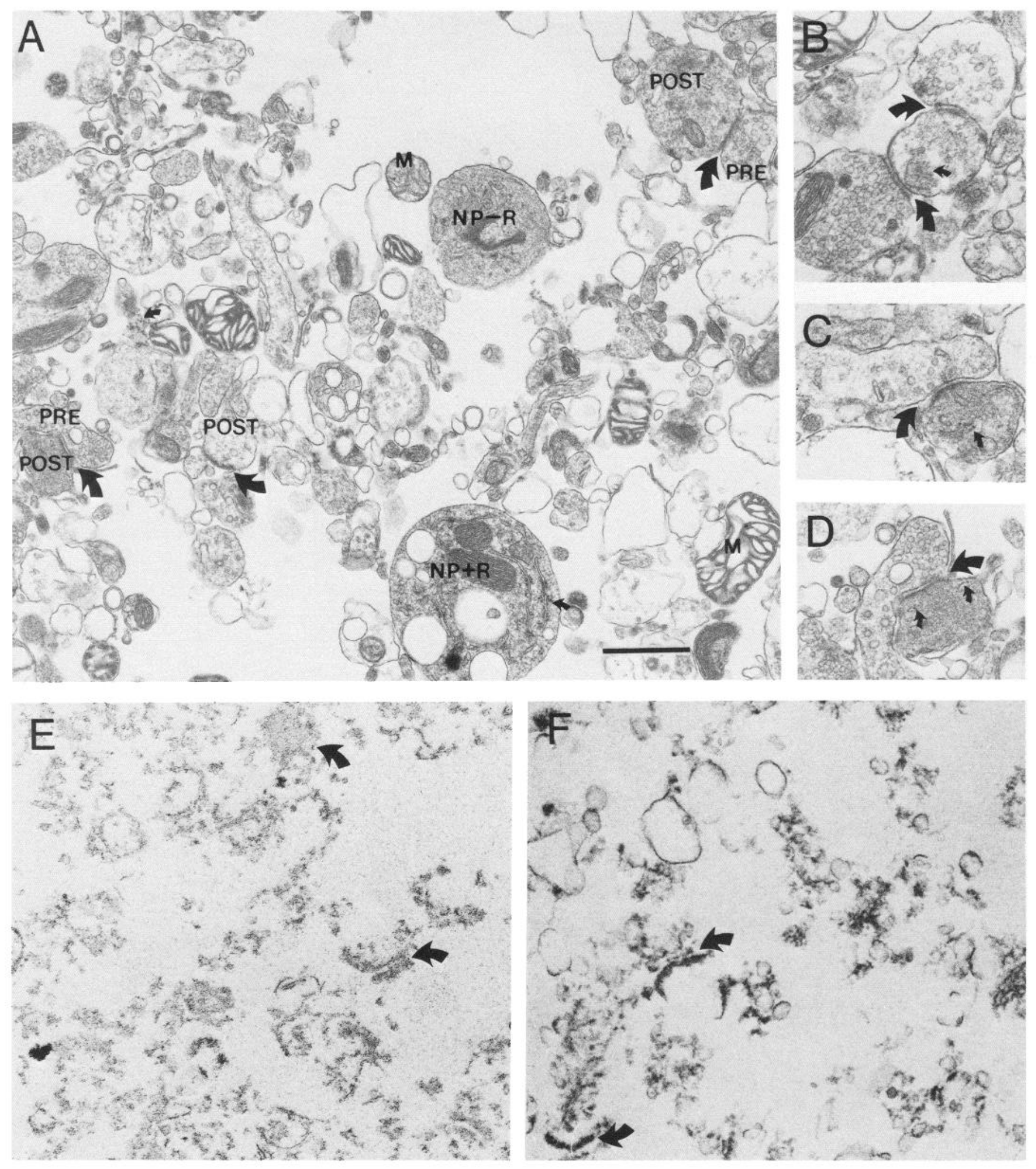

Figure 2. Composition of synaptosome and SJC fractions. $A-D$, Electron micrographs of synaptosome preparation from 16-d-old rat pups. Large arrows indicate synaptic junctions or postsynaptic densities; small arrows indicate polyribosomes. $A$, Representative field showing the membranebound profiles that were counted in our study. $P R E$, a presynaptic profile; $N P+R$, a nonpresynaptic profile containing polyribosomes; $N P-R$, a nonpresynaptic profile without ribosomes; $M$, a mitochondrion. $P O S T$ shows a postsynaptic profile. $B$, Two presynaptic profiles are apposed to a postsynaptic profile that encloses polyribosomes that seem to be attached to membranous elements. $C$ and $D$, A presynaptic profile, attached to a postsynaptic profile that contains free polyribosomes. $E$ and $F$, Electron micrographs of two SJC samples. $E$, A PSD-enriched sample that is overextracted. $F$, A fraction contaminated with membrane. Arrows indicate PSDs. Scale bar in $A$ corresponds to $1 \mu \mathrm{m}$ in $A, 0.68 \mu \mathrm{m}$ in $B$ and $C, 0.64$ $\mu \mathrm{m}$ in $D$, and $0.42 \mu \mathrm{m}$ in $E$ and $F$. 
fixed in $2 \%$ paraformaldehyde $/ 2 \%$ glutaraldehyde, pelleted at $48,000 \times$ $g \times 30 \mathrm{~min}$ in fix, postfixed in osmium tetroxide, dehydrated, and embedded in Maraglas resin. The pellet was then sectioned through its thickness at $600-700 \AA$ on an LKB ultramicrotome. The sections were collected on 200-mesh grids, double-stained with uranyl acetate in methanol and lead citrate, and photographed using an Hitachi HU12A electron microscope. Photomicrographs were taken through the depth of the pellet, 1-2 pictures/grid square at 10,000 or $8,000 \times$ original magnification. Usually 5-10 micrographs were obtained for each pellet.

Electron microscopic examination of the synaptosomes was performed for $10^{35} \mathrm{~S}$ labeling experiments. The synaptosome preparations were similar in composition and appearance to those previously described. The composition of the synaptosomal fraction was quantitatively assessed in five preparations using a stereological approach. A grid overlay was prepared that corresponded to $1 \mu \mathrm{m}^{2}$ on the photomicrographs. Profiles at grid intersections were classified as one of the following five types: (1) presynaptic, containing at least three synaptic vesicles; (2) nonpresynaptic profiles, without ribosomes, but containing cytoplasm; (3) nonpresynaptic profiles, with ribosomes; (4) mitochondria (double-walled, with the inner wall extending projections into the lumen of the organelle); or (5) other types such as membrane ghosts or small vesicles or no profile beneath the intersection. The first four classes constitute the cytoplasm-containing organelles of the fraction; the relative amount of each of the four kinds is reported as a percentage of the total of all four classes.

Electron microscopic evaluation of each of the subfractions of the gradient preparations from two experiments confirmed that our synaptosome samples produced membrane subfractions with the expected composition (data not shown). The lightest subfraction (Band 1) was primarily composed of empty multilamellate myelin, but other smaller cytoplasm-containing membrane particles were also occasionally seen, along with some mitochondria trapped within the myelin fragments. Band 2 consisted of much smaller empty membrane particles and broken membranes, with little or no myclin. Band 3 contained membranc and broken membranes of the same size as in band 2, but many of the membranes showed electron-dense thickenings. The pellet was enriched in mitochondria but also contained cytoplasm-containing membrane particles and empty membranes.

EM evaluation of the SJC was performed for 8 of the 11 preparations, while the SPM was examined in 6 experiments. These analyses revealed that two of the SPM samples were contaminated with unidentifiable membrane components. The characteristic electron-dense PSDs and occasional intact SJCs with little or no contamination with membranes were seen in three SJC preparations. In one other preparation, the PSDs appeared thinner and more extracted and no membrane was seen. Four SJC preparations were significantly contaminated with membrane. Although less pure than the first type of preparation, these fractions were still enriched for SJCs in comparison to the parent SPM fraction. These two different types of preparation are illustrated in Figure 2. The results are expressed including and excluding the less pure preparations.

Biochemical analysis. Fractions collected for biochemical analysis were aliquoted and stored at $-80^{\circ} \mathrm{C}$. Before use, they were dissolved in $0.5 \mathrm{~N} \mathrm{NaOH}$ for protein assay and scintillation counting or in Laemmli sample buffer for SDS-PAGE analysis. Protein assays were by the method of Bradford (1976) or by the BCA assay (Smith et al., 1985). Liquid scintillation counting was in NEN Aquasol scintillation cocktail on a Beckman LS-233 or LKB 1209 Rackbeta liquid scintillation system. Specific activity (s.a.) values are reported as $\mathrm{cpm} / \mu \mathrm{g}$ protein \pm SEM. Inhibition is described in terms of percent inhibition $=[$ (s.a. control s.a. inhibited)/s.a. control] $\times 100$. Differences between control- and inhibitor-treated samples were evaluated statistically using the Wilcoxon sign rank test for paired samples. When the number of samples was too low for a Wilcoxon test (for the SJC samples) we used a $t$ test for paired samples. Differences between CSM, SPM, and SJC specific activity were evaluated using a two-way ANOVA for a single subject with repeated measures and then a Fisher Protected Least Significant Difference test.

SDS-PAGE of the samples was carried out on $10 \%, 5-15 \%$, or $7.5-$ $15 \%$ gradient gels, $0.75 \mathrm{~mm}$ thick and 8,16 , or $24 \mathrm{~cm}$ in length, by the method of I aemmli (1970). Some gels contained $4 \mathrm{~m}$ urea in stacking and resolving gels and were used to separate samples treated with $4 \mathrm{M}$ urea. Gels were stained in an ammonium sulfate/Coomassie Blue solution by the method of Neuhoff et al. (1985). The gels were photographed and then impregnated with NEN Enhance and dried onto Whatman \#1 filter paper. Fluorographs were prepared by exposing X-Omat AR film to the dried gels at $-80^{\circ} \mathrm{C}$ for $4-20 \mathrm{~d}$.

\section{Results}

\section{Composition of synaptosome fractions}

Figure $2 A$ illustrates the overall composition of a representative synaptosome fraction from 16-d-old animals. These fractions contained a large number of presynaptic boutons identifiable by the presynaptic vesicles they contained (PRE). Mitochondria (M) were often present within the presynaptic boutons. Free mitochondria were also present. Ribosome containing elements $(\mathrm{NP}+\mathrm{R})$ were present, some of them displaying a postsynaptic density (Fig. $2 B-D$ ). Some of the presumptive postsynaptic fragments were attached to presynaptic boutons, but more often ribosome-containing profiles were not obviously related to a presynaptic terminal. Most ribosome-containing clements did not display a PSD. A large number of cytoplasm-containing profiles were present that did not have visible ribosomes or synaptic vesicles (NP-R). These profiles also sometimes bore a PSD. The filamentous cytoplasm of some of the profiles suggested that they might be of glial origin, but such profiles were rare. No intact nuclei were present, but some fragmented nuclei were seen.

The composition of synaptosomal fractions was quantitatively estimated in five preparations by point counting. Of the cytoplasm-containing membrane-bound profiles in the fraction, $22.7 \pm 2.4 \%$ were presynaptic profiles; $57.1 \pm 2.4 \%$ were nonpresynaptic, without apparent ribosomes; $10.7 \pm 0.6 \%$ were nonpresynaptic with ribosomes; and $10.5 \pm 1.6 \%$ were mitochondrial.

\section{Synaptosomal protein synthesis}

When synaptosomes were incubated in a medium containing $10 \mu \mathrm{Ci} / \mathrm{ml}^{3} \mathrm{H}$-leucine, the rate of incorporation of label into TCA-insoluble protein began to decrease after about $45 \mathrm{~min}$ (Fig. 3A). Thus, a 45 min incubation time was used in all subsequent experiments. Rat pups of different ages were used to prepare synaptosomes that were then compared for their protein synthetic activity (Fig. 3B). The extent of incorporation appeared to be higher in the younger animals, although there was considerable variability. Subsequent studies used synaptosomes prepared from rat pups that were $13-26 \mathrm{~d}$ old.

\section{Contribution of mitochondrial versus eucaryotic cellular protein synthesis to the overall incorporation}

The contribution of mitochondrial and eucaryotic cellular protein synthesis to synaptosomal incorporation was evaluated using selective protein synthesis inhibitors. CAP inhibits mitochondrial protein synthesis (Wheeldon and Lehninger, 1966), CYC inhibits eucaryotic protein synthesis (Ennis and Lubin, 1964), and RNase would be expected to destroy RNA that is not contained in membrane-enclosed structures (Appel et al., 1967), thus inhibiting protein synthesis in free microsomes that are a contaminant of the fraction. In eight experiments, we compared the extent of incorporation in control preparations with preparations incubated with CAP (in all eight experiments), CYC (five of eight experiments), and RNase (two of eight experiments). For these experiments, the synaptosomal preparation was divided equally between the conditions. Since we also planned to use SDS-PAGE and fluorography to determine whether the inhibitors affected the synthesis of particular proteins, these experiments were carried out using ${ }^{35} \mathrm{~S}$-methionine for the labeling. In the presence of CYC (at a concentration of $500 \mu \mathrm{g} / \mathrm{ml}$ ), overall incorporation was inhibited by $42.9 \% \pm$ 

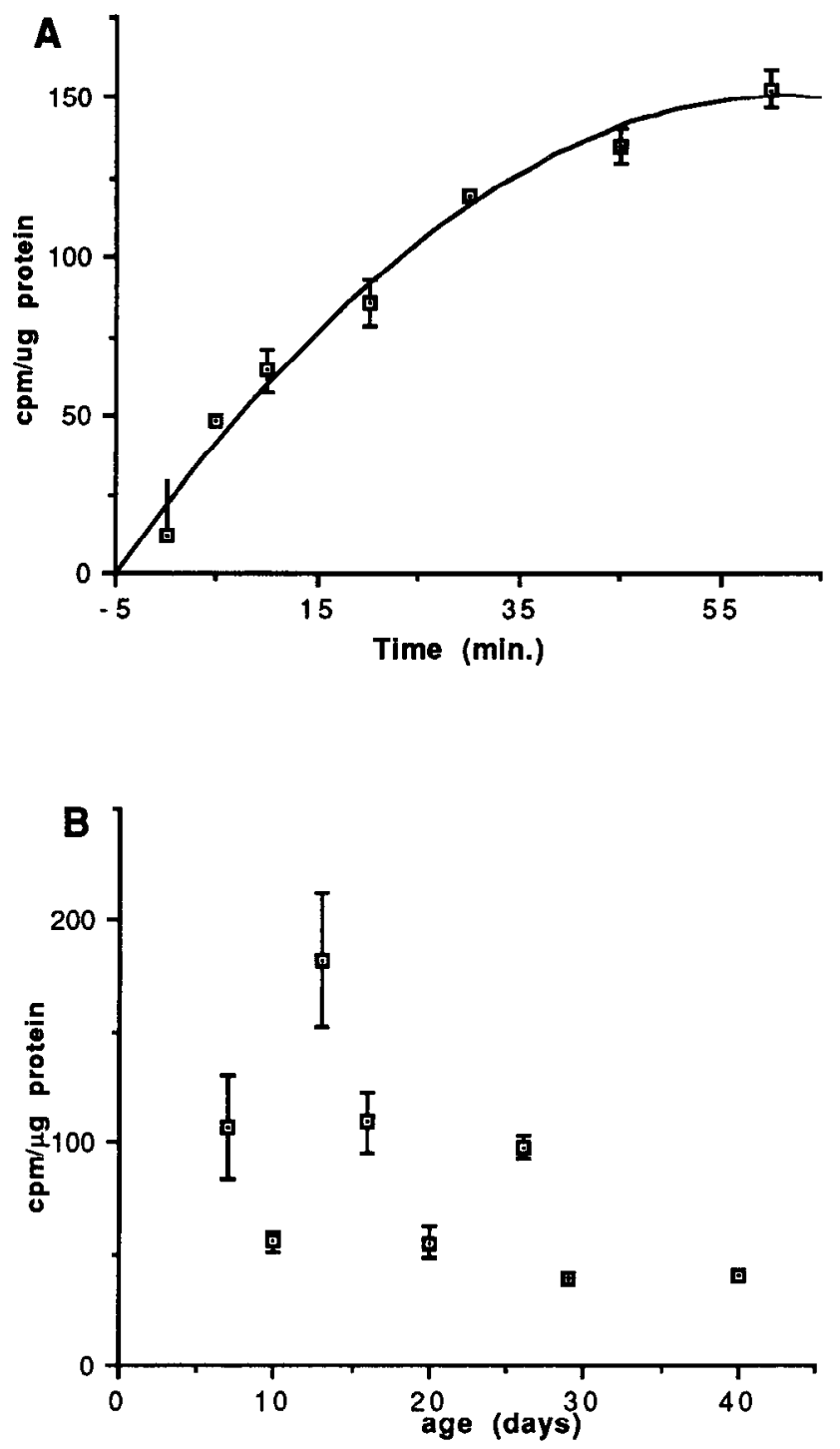

Figure 3. Incorporation of labeled amino acid into protein in synaptosome fractions. $A$, Time course of incorporation of ${ }^{3} \mathrm{H}$-leucine into the TCA-precipitable component of synaptosomes prepared from 16d-old rat pups. $B$, Protein synthesis (reported as $\mathrm{cpm} / \mu \mathrm{g}$ protein) in synaptosomes prepared from rat pups of different ages and incubated with ${ }^{3} \mathrm{H}$-leucine for $45 \mathrm{~min}$ as described in Materials and Methods.

$11.5 \%(p<0.05)$. There was no significant inhibition when synaptosomes were incubated in the presence of CAP $(50 \mu \mathrm{g})$ $\mathrm{ml}, \%$ difference $=10.24 \pm 17.9 \%)$ or RNase $(10$ or $50 \mu \mathrm{g} / \mathrm{ml}$, $\%$ difference $=3.67 \pm 12.37 \%$ ). Neither of these changes were significant $(p>0.05)$. These results suggest that incorporation by miluchondria or free microsomes accounted for relatively little of the overall incorporation in the unfractionated synaptosomes.

A more revealing way to evaluate the contribution of eucaryotic ribosomal versus mitochondrial protein synthesis uses gel fluorography to identify which protein species are labeled in the presence of the various inhibitors (Irwin, 1985). An example from one preparation that had been incubated with or without the inhibitors is illustrated in Figure 4. For these gels, the soluble and membrane fractions werc cvaluatcd separately (see Fig. 4 legend). Equal amounts of protein from control-, CYC-, and CAP-treated synaptosomes were loaded on the gel, as evidenced by the Coomassie-stained gel (Fig. 4, left). CYC inhibited incorporation into a large number of bands throughout the gel, but particularly in the higher molecular weight range (above 50 $\mathrm{kDa}$ ). However, a few labeled bands were still evident in the low molecular weight range (below $30 \mathrm{kDa}$ ) in synaptosomes treated with CYC. CAP inhibited labeling of the low molecular weight bands whose labeling was not inhibited by CYC but did not apparently affect the labeling of the bands that were affected by CYC. The fact that labeling of a large number of bands was not appreciably affected by CAP suggests that most of the protein synthesis in the synaptosomal fraction is nonmitochondrial. In general, these results confirm the report of Irwin (1985). RNase did not appreciably affect the pattern of labeled bands, although the overall labeling appeared to be slightly reduced (data not shown). Thus, any proteins synthesized by free microsomes were not obviously of a different class than the proteins synthesized within membrane-bound elements.

Heavy diffuse labeling was always seen at the top of the nonurea gel at the interface between the resolving and stacking gels. In the CSM sample, this diffuse labeling that did not resolve into bands was still evident in the samples from CYC-treated synaptosomes but was slightly less evident in the CAP-treated synaptosome preparation. A corresponding protein smear is not apparent in the Coomassie-stained gel. This diffuse labeling was not apparent in samples prepared with urea (see below).

\section{Subfractionation of the labeled synaptosomes}

The SPM fraction is enriched for membrane particles bearing synaptic specializations; the SJC fraction is the Triton-insoluble part of the SPM, the pre- and postsynaptic specializations joined by the synaptic junction with a small amount of associated membrane (Cotman and Taylor, 1972). Our expectation was that if dendritic polyribosomes manufacture synaptic proteins, some labeled protein should appear in the SPM and SJC fractions after synaptosomal incorporation of labeled amino acid. We found that the SPM and SJC fractions from labeled synaptosomes were in fact labeled (SPM s.a. $-857 \pm 207$; SJC s.a. $=748 \pm 196$ ). However, there are a number of other potential sources of this labeling that must be considered before the labeling can be ascribed to local synthesis of synaptic protein.

One possibility that must be considered is that the labeled protein in the SPM and SJC fractions represents the presence of contaminating nonsynaptic membranes that are labeled. Two lines of evidence argue against this possibility. First, in subfractionating the CSM to the level of the SPM and then the SJC we are enriching for postsynaptic specializations and decreasing the quantity of nonsynaptic membrane. If nonsynaptic membrane is the carrier of labeled protein in these synapse-enriched fractions, then the specific activity of the sample should decrease as nonsynaptic membrane is removed. Second, if nonsynaptic membrane contaminants are the source of label in the SPM, the specific activity of other bands on the gradient that are possible sources for such contaminants should be higher than that of the SPM.

As illustrated in Figure 5, the specific activity of the SJC fraction from all experiments was not significantly lower than that of the SPM from which it was derived. The specific activities of both SPM and SJC fractions were significantly lower than the specific activity of the CSM. However, in CAP-treated synaptosomes, where mitochondrial labeling is reduced (and the remaining incorporation reflects eucaryotic ribosomal protein synthesis) there was no significant difference in the specific ac- 

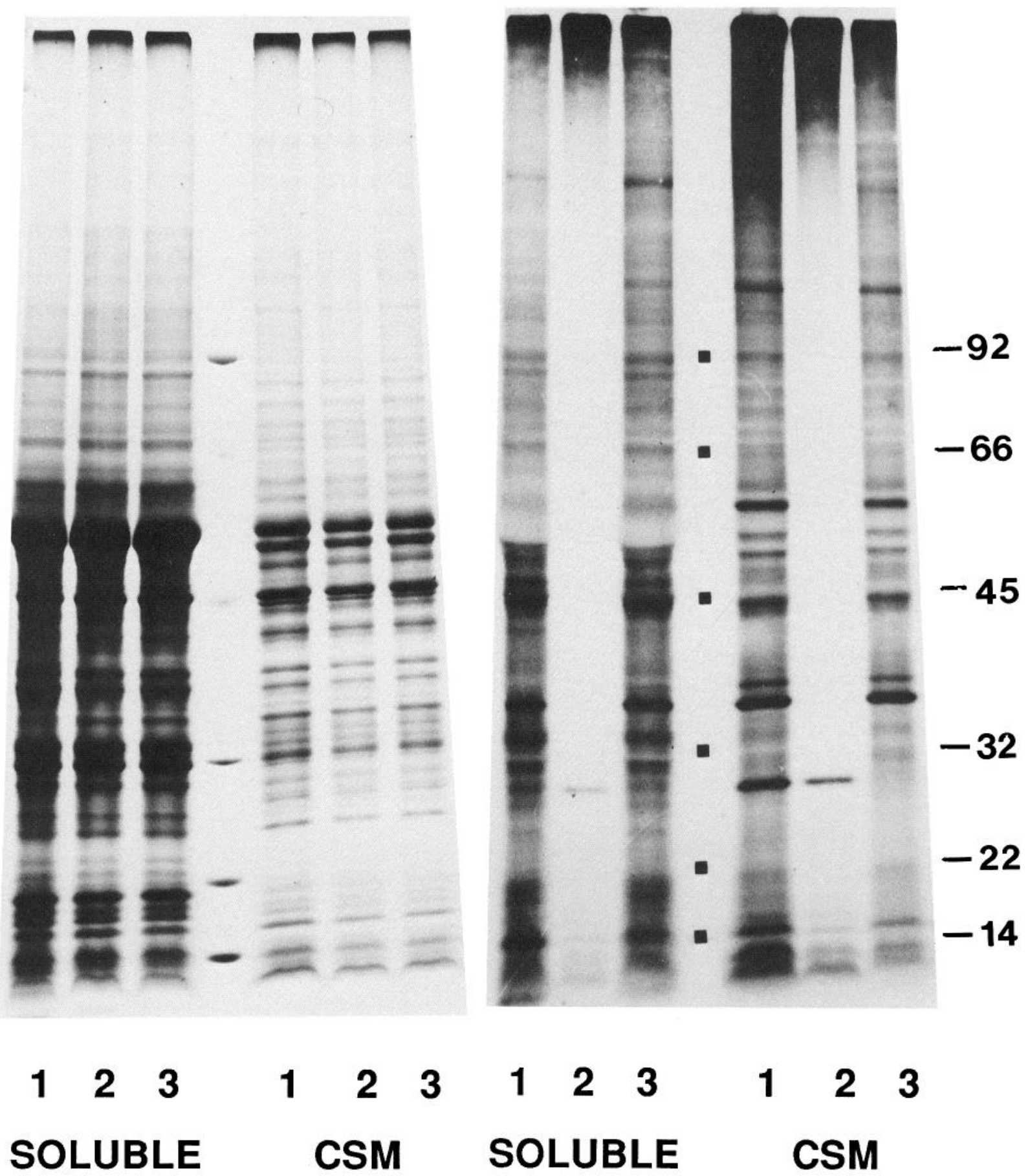

Figure 4. SDS-PAGE analysis of protein synthesis in synaptosomes. Synaptosomes prepared from 13-d-old rat pups were incubated with ${ }^{35}$ Smethionine as described in Materials and Methods. The soluble and membrane components of the labeled synaptosomes were separated as described in Materials and Methods. Samples from control (I), cycloheximide-treated (2), and chloramphenicol-treated (3) labeled synaptosomes were loaded on a $7.5-15 \%$ gradient gel. The membrane samples (CSM) had approximately $213,000 \mathrm{cpm}$ in the control; the soluble samples approximately $91,000 \mathrm{cpm}$. $A$, Serva Coomassie Blue R/ammonium sulfate-stained gel prepared as in Neuhoff et al. (1985). $B$, Fluorograph (5 d exposure). The protein load for the soluble samples appears to be approximately twice that for the membrane samples. The positions of molecular weight standards of the indicated molecular weight $(\times 1000 \mathrm{Da})$ are indicated on the right.

tivity of CSM, SPM, and SJC. In the four experiments that produced SJC fractions judged to be of highest purity based on electron microscopic evaluation, the specific activity of the SJC fraction was actually higher than that of the parent SPM subfraction (1133 \pm 359 vs. $791.5 \pm 253.6)$, although this difference was not statistically significant.
Moreover, as illustrated in Figure 6, the specific activity of the SPM was approximately equal to that of Bands 1 and 2 ( $857.1 \pm 207$ vs. $683.3 \pm 168$ and $744.8 \pm 204$, respectively). This indicates that labeling of the SPM fraction is not likely to be due to contamination of the SPM by other nonmitochondrial membrane components of the synaptosome. On the other hand, 

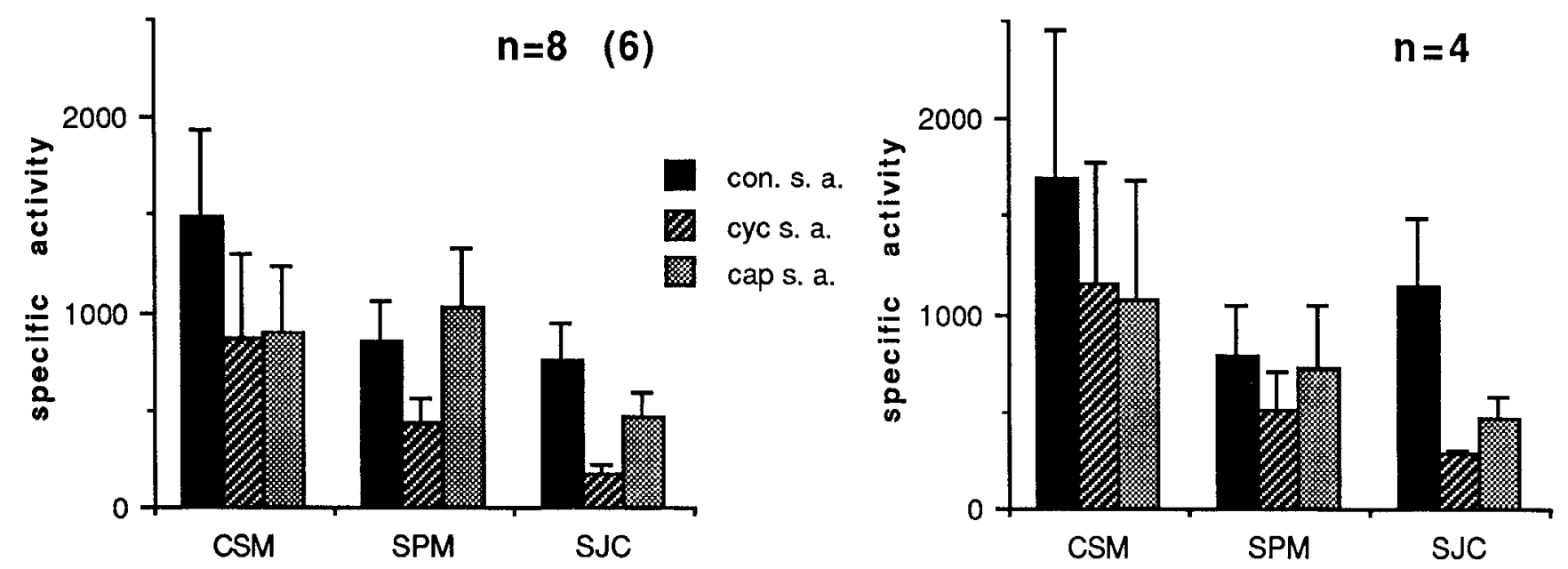

Figure 5. Comparison of specific activity values of CSM, SPM, and SJC samples from eight (control and chloramphenicol) or six (cycloheximide) preparations (left) and from the four preparations with the purest $S J C$ samples (right). con., control; cyc., cycloheximide; cap., chloramphenicol.

the mitochondrial subfraction obtained from the synaptosomes did have a higher specific activity than that of the SPM (1385 \pm 335 vs. $857 \pm 207$ ). Thus, contamination by the mitochondrial fraction could not be excluded.

To evaluate the possibility that labeling of the SPM is due to mitochondrial contamination, we compared the specific activities of the membrane subfractions after synaptosomal incorporation in the presence of chloramphenicol and cycloheximide. If labeling in the SPM is due to mitochondria, the specific activity should be reduced in the SPM as it is in the mitochondrial fraction in CAP-treated synaptosomes. Alternatively, if the labeled protein in the SPM is synthesized by eucaryotic ribosomes, labeling of the SPM should be sensitive to CYC. In six experiments, both CAP and CYC were used. In two experiments, only CAP was used. As illustrated in Figure 6, labeling of the mitochondrial pellet was reduced by an average of $47.1 \%$ (to $732.9 \pm 186)$ in CAP-treated synaptosomes $(p<0.05)$. There was no decrease in labeling of the SPM. In fact, labeling of the SPM fraction obtained from CAP-treated synaptosomes was actually $19.1 \%$ higher $(1021 \pm 302)$ than the SPM from control synaptosomes $(p=0.37, \mathrm{NS})$. Therefore, in a medium where mitochondrial synthesis is reduced to a minimum, labeling of proteins of the SPM remained high. Labeling in all membrane subfractions was significantly inhibited by CYC (Fig. 6). These results suggest that the labeling in the SPM is not due to contamination by mitochondria.

Comparison of the specific activity of subfractions from the experiments in which the SPM samples were judged to be most pure yielded results that were similar to those described above for the total of eight experiments. The mitochondrial fraction again had the highest specific activity, and this labeling was CAP sensitive. The SPM labeling was lower than that in the mitochondrial fraction $(791.5 \pm 254)$ but was comparable to the other membrane subfractions and was not reduced by CAP. Labeling of all subfractions was reduced by CYC. Taken together, these results suggest that the label was intrinsic to SPM and was not due to contamination by other bands.

In order to gauge the extent of the label due to mitochondrial contamination of the $\mathrm{SJC}$, the specific activities of SJCs derived from control-, CYC-, and CAP-treated synaptosomes were compared. The specific activity of the SJC obtained from CAP- treated synaptosomes was $24 \% \pm 14.6 \%$ lower than that in paired controls $(n=8)$, but this decrease was not significant, whereas the specific activity of the SJC derived from CYCtreated synaptosomes was decreased by $65 \pm 7.6 \%(p<0.05)$ in six experiments. In the four purer SJC samples, the labeling was reduced by $66.9 \pm 12.3 \%$ in CYC-treated and by $52.7 \pm$ $12.7 \%$ in CAP-treated SJC ( $p>0.05$ by $t$ test for both, NS). Taken together, these results indicate that most of the labeling in SPM and SJC fractions appears to reflect eucaryotic protein synthesis, a conclusion that is strongly supported by the fluorographic analyses (see below).

\section{Characterization of labeled synaptic proteins}

Gel analysis of the SPM and SJC. SPM samples from $11 \mathrm{ex}-$ periments and SJC samples from 10 experiments were analyzed by SDS-PAGE and fluorography. In three experiments, the Triton extract of the SPM was also analyzed. In three of these experiments, the samples were run on urea-containing gels, while seven sets were analyzed on nonurea gels.

Gels were loaded with equal protein from control preparations and samples from the same preparation that had been labeled in the presence of CYC or CAP. The inhibitor treatment allowed us to identify any mitochondrially synthesized protein present in these samples. One such urea gel analysis is illustrated in Figure 7. All the labeled bands seen in the SPM, SJC, and Triton extract are CYC-sensitive and CAP-resistant and are therefore manufactured by eucaryotic ribosomal systems. In the SPM sample, the most prominent labeled bands are at approximately 36 and $60 \mathrm{kDa}$. Other labeled bands are evident at approximatcly $14,18,24,32,36,38,42,45,48,50,52,55,58,60,92$, $100,116,180,200$, and $220 \mathrm{kDa}$. Of these, the bands at 36,42 , $48,50,60,116$, and $220 \mathrm{kDa}$ are most heavily labeled.

Triton extraction solubilizes nonsynaptic membrane in the SPM fraction leaving PSDs with small amounts of membrane attached, so that the Triton-insoluble SJC fraction is enriched in the core polypeptides of the PSD and the synaptic complex (Cotman and Taylor, 1972). As seen in Figure 7, the labeled bands in the SPM sample at 24, 32, and $36 \mathrm{kDa}$ are removed by Triton extraction, since they are prominent in the Triton extract and only very faintly evident in the SJC sample. Other than these three labeled bands, all the others are seen in the SJC 

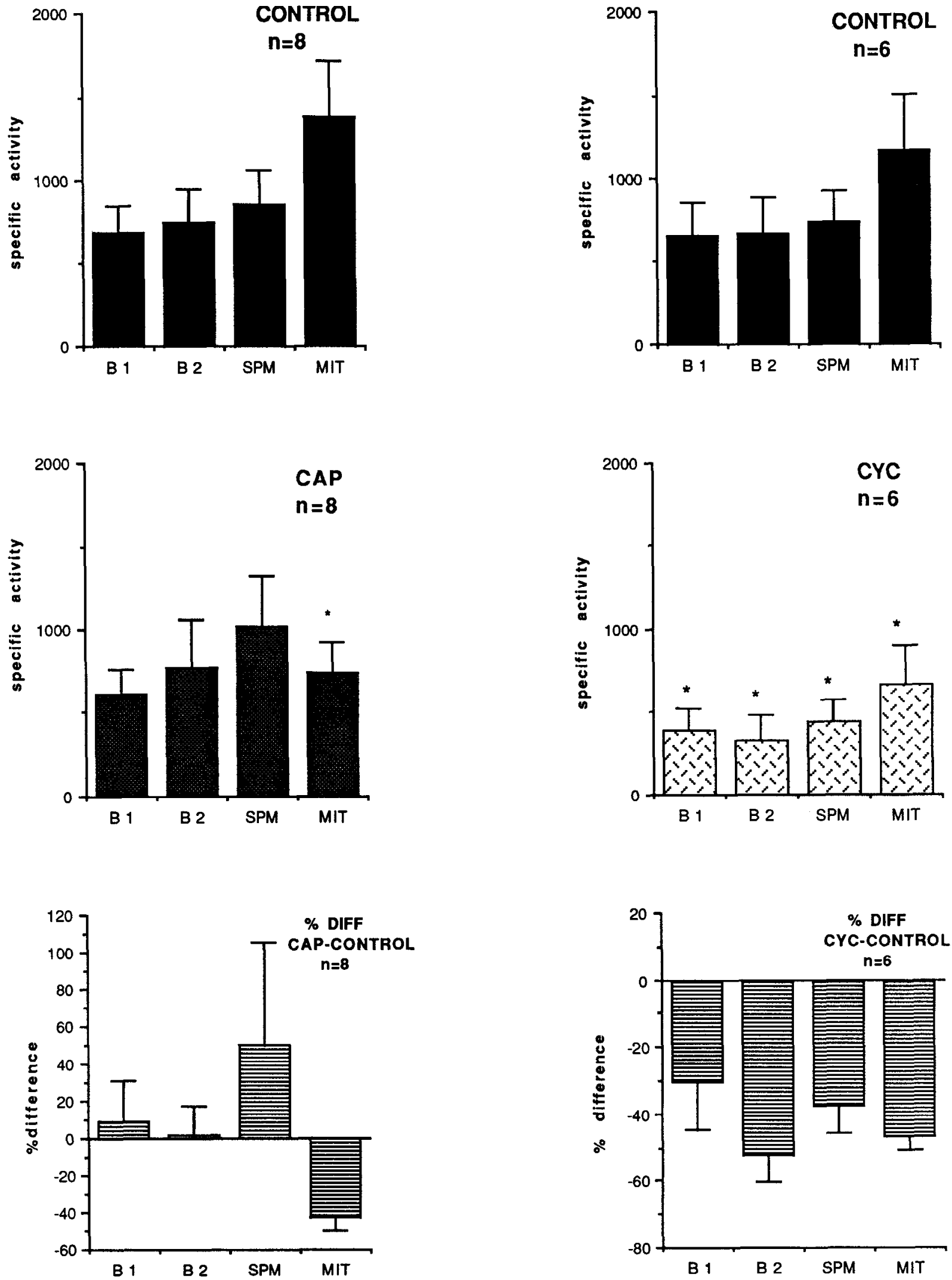

Figure 6. Subfractionation of membrane components of labeled synaptosomes. Graphs showing specific activity of control-, CAP-, and CYCtreated subfractions from labeled synaptosomes and the percent difference between control- and inhibitor-treated specific activity values. Values from the eight experiments where $C A P$ was used are on the left while the six experiments where CYC treatment was performed are shown on the right. $[\%$ difference $=($ inhibitor specific activity - control specific activity $) /$ control specific activity $\times 100.1$ 


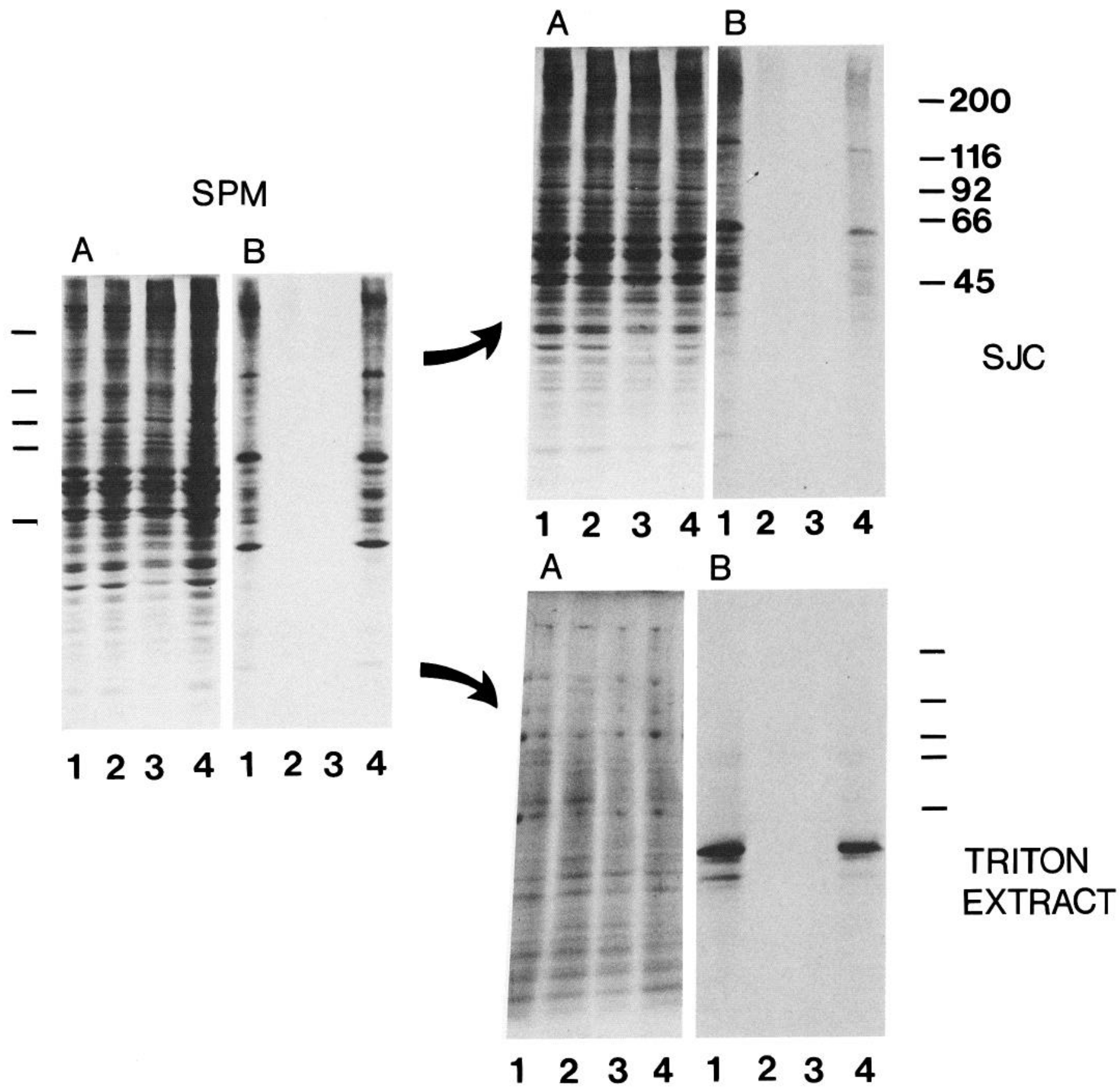

Figure 7. Comparison of labeled protein in the SPM, the SJC, and the Triton-soluble portion of the SPM. Synaptosomes prepared from 21-dold rat pups were labeled with ${ }^{35} \mathrm{~S}$-methionine and subfractionated as described in Materials and Methods. Approximately $2.5 \mu \mathrm{g}$ of protein from subfractions of control ( $I$ ), cycloheximide-treated (2), cycloheximide and chloramphenicol-treated (3), and chloramphenicol-treated (4) synaptosomes were loaded on a $5-15 \%$ gradient $4 \mathrm{~m}$ urea gel. The cpm in control samples was about $460 \mathrm{cpm}(S J C)$. A, Serva Coomassie Blue/ammonium sulfatestained gel, prepared as in Neuhoff et al. (1985). B. Fluorograph (15 d exposure). The positions of molecular weight standards of the indicated molecular weight $(\times 1000 \mathrm{Da})$ are indicated on the right.

and are resistant to solubilization. In the total of three preparations analyzed in this fashion, the $32-$ and $36-\mathrm{kDa}$ bands were almost totally extracted in two, while one sample had these labeled bands in both extract and SJC.

In general, between 8 and 15 labeled bands were seen in the SPM and SJC samples run on nonurea gels, while urea gels showed 8-20 labeled bands. In some preparations, CYC-resistant, CAP-sensitive (i.e., mitochondrially synthesized) labeled bands were faintly evident in the SPM sample, but not in the SJC.

In the experiments where regular SDS-PAGE gels were run, bands at $36,38,42,45$, and $55 \mathrm{kDa}$ were seen in all SPM preparations, while bands at 14,18 , and $60 \mathrm{kDa}$ were seen in seven of eight preparations and bands at 26,28 , and $116 \mathrm{kDa}$ were seen in six of eight preparations. Other bands at 24,32 , $50,52,92$, and $180 \mathrm{kDa}$ were only occasionally seen. In gels of 
the SJC preparations, the labeled bands at $38,42,45,55,60$, and $116 \mathrm{kDa}$ were seen in all seven preparations, while the one at $36 \mathrm{kDa}$ was seen in six of seven. The bands at 14,28 , and $50 \mathrm{kDa}$ were seen in five of seven preparations. The other labeled bands seen in the SPM were only occasionally evident in fluorographs of the SJC.

Similarly prepared samples solubilized in urea/SDS buffers and run on urea-containing SDS gels showed some differences in the pattern of label, although the distribution of labeled bands between different subfractions and the susceptibility of labeling to the two inhibitors was similar to that described above. Prominent diffuse labeling seen at the top of nonurea gels was not seen in urea gels. High molecular weight bands at 92, 100, 116, 180,200 , and $220 \mathrm{kDa}$ were more clearly evident in three of three SPM preparations, and bands at 60 and $116 \mathrm{kDa}$ were much more prominent than in nonurea gels. Furthermore, several bands between 40 and $60 \mathrm{kDa}$ that were either not secn or not clearly resolved in nonurea gels were more distinct in the urea gels.

Of the two most prominently labeled bands in the SPM preparation, the band at $60 \mathrm{kDa}$ did not colocalize with any perceptible Coomassie staining, while the band at $36 \mathrm{kDa}$ was at approximately the same position as a minor Coomassie band. In the SJC sample, although in two of three experiments most of the label at $36 \mathrm{kDa}$ was solubulized by Triton extraction, the minor Coomassie-stained band in that region was still perceptible. In contrast to the SPM sample, the labeled band at 60 $\mathrm{kDa}$ in the SJC sample did in some cases colocalize with a very faint Coomassie-stained band.

Gel analysis of all synaptosomal membranes. Of the complement of proteins present in synaptic plasma membranes, some are enriched when compared to other cell membranes while others are widely distributed membrane protcins (Kclly and Montgomery, 1982; Beesely, 1989; Gurd, 1989). To evaluate whether the labeled proteins in the SPM fraction were also present in other subfractions of the labeled synaptosome, all the membrane subfractions were analyzed with SDS-PAGE and fluorography in 11 experiments. The gels were prepared by loading equal amounts of protein from subfraction samples derived from synaptosomes treated with CYC, CAP, or no inhibitor. One such gel analysis is illustrated in Figure 8. The Coomassie staining pattern indicated substantial differences in the protein composition of the subfractions; the fluorographs, however, revealed that the major CYC-sensitive bands in the SPM were also present in other membrane components of the synaptosome, including all of the bands present in the SJC fractions. However, the relative density of labeling of bands differed between different subfractions. Since all but three of the labeled polypeptides were present in the Triton-insoluble part of the SPM but not in the Triton-soluble extract, they are presumably components of the Triton-insoluble S.C. The presence of labeled bands in these other membrane fractions may be an indication that they are widely distributed membrane proteins or that the other membranes also contain SJC as a contaminant. Both Band 2 and mitochondria have been shown to be contaminated to some extent with SJC-like structures (Kelly and Montgomery, 1982).

\section{Is the labeling of the SJC fraction the result of adventitious binding of labeled soluble proteins?}

One possible source of labeled protein in SJC fractions is labeled soluble protein that may artefactually adhere to the SJC during isolation (Matus et al., 1980; Carlin et al., 1982). To evaluate this possibility, two synaptosomal preparations were incubated as above, one with ${ }^{35} \mathrm{~S}$-methionine (control) and one without (cold). After incorporation, the two preparations were pelleted and subjected to osmotic shock. The labeled and unlabeled soluble protein released into the supernatant was collected after pelleting the membrane. The soluble protein from labeled synaptosomes was added to the membrane pellet from the cold preparation, and the suspension was incubated for $10 \mathrm{~min}$. The membrane pellet was then collected from the labeled and cold preparations and subjected to the usual fractionation procedure. If labeled soluble protein binds to the $\mathrm{SJC}$, then this binding should be evident in the cold SJC preparation that had been exposed to labeled soluble protein.

In two experiments, the specific activity of the SPM from cold synaptosomes was $5.6 \%$ and $7.4 \%$ of the labeled preparation and that of the SJC was $7.3 \%$ and $1.2 \%$. These results indicate that only a small percentage of the labeling of the SPM and SJC seen in control preparations could be due to adventitious binding of soluble proteins.

It is important to note that the conditions during which exposure to labeled soluble proteins took place in the above experiment may not allow adventitious binding to occur to the same extent as in labeled synaptosomes. However, even though the amount of labeled protein adhering may be decreased due to this limitation, if any labeled soluble protein is adherent, the same labeled bands evident in fluorographs of the control preparation should be evident in the cold preparation, although less prominently. Thus, fluorographs of control (labeled) and cold preparations from the experiments above were compared. As illustrated in Figure 9, no labeled bands were evident in the fluorographs of the cold preparation.

\section{Discussion}

This experiment tested the hypothesis that some synaptic proteins are locally synthesized within dendrites. Synaptosome fractions were used as the test system since previous studies indicated that they contained dendrite fragments (separated from the cell body) that were capable of protein synthesis (Autilio et al., 1968; Cotman and Taylor, 1971; Verity et al., 1980). Some of these dendrite fragments in our preparations clearly displayed the protein synthetic apparatus localized beneath the postsynaptic specialization (Fig. $2 B-D$ ). We confirmed findings from previous studies (Autilio et al., 1968; Morgan, 1970; Deanin and Gordon, 1973; Verity et al., 1980; Irwin, 1985) that showed that (1) synaptosomes incorporated labeled amino acids into protein, (2) CAP-sensitive incorporation accounted for only a minor part of the total protein synthetic activity but accounted for a substantial proportion of the incorporation into fractions that were likely to include mitochondria, (3) incorporation into all subfractions was sensitive to CYC, and (4) CYC and CAP inhibited the labeling of different polypeptides. Our further finding was that the SJC and SPM fractions from labeled synaptosomes showed a high specific activity that was not due to contamination by other membrane fractions. Moreover, the labeling of the polypeptides in the SPM and SJC fractions (as revealed by PAGE and fluorography) was sensitive to CYC and not CAP. These data are consistent with the hypothesis that a synapse-associated protein synthetic system exists in the synaptosomal preparation, which manufactures proteins that become an integral part of the SPM and SJC.

One alternate explanation of these results is that the $\mathrm{SJC}$ is 


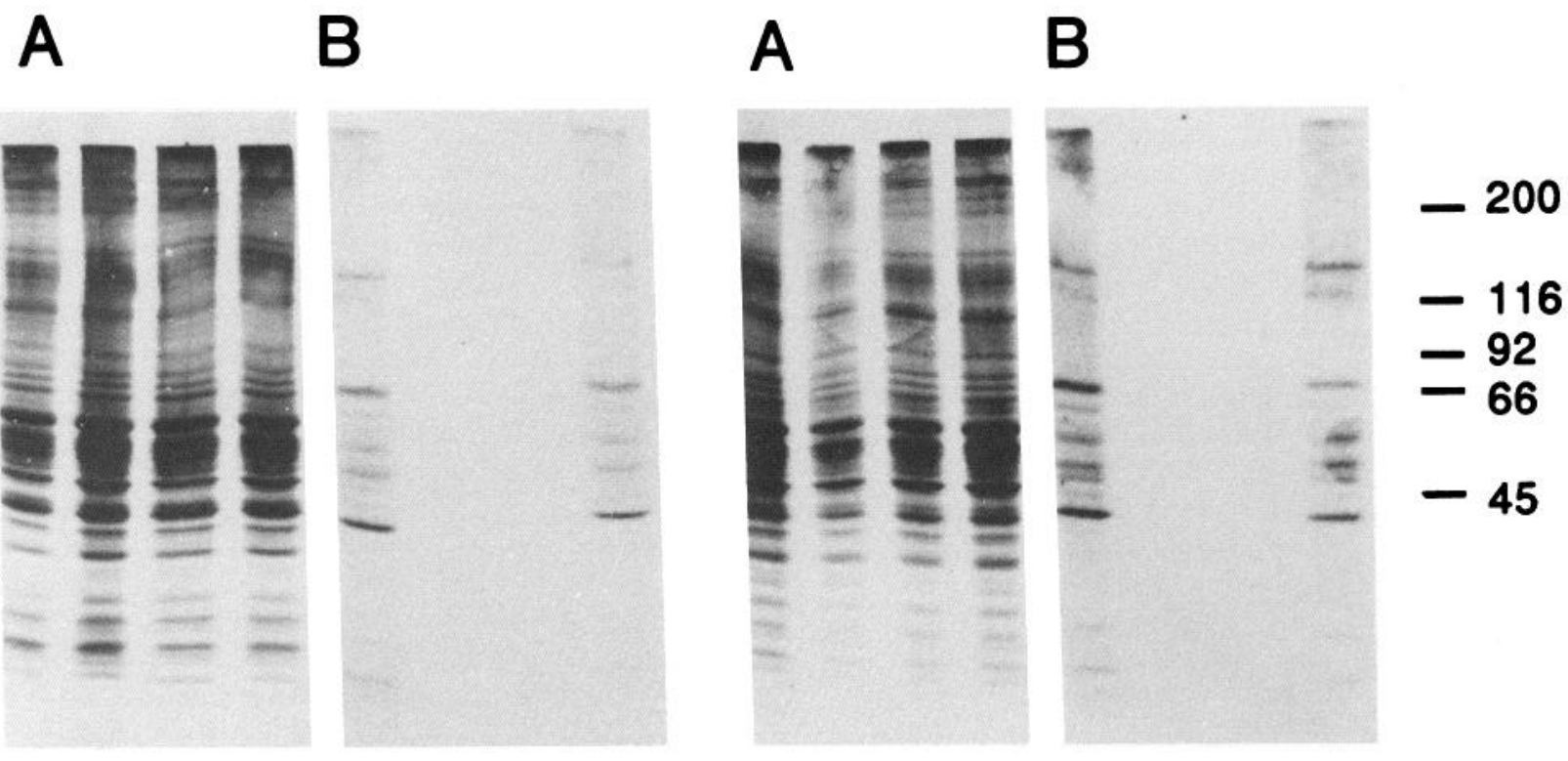

\section{$\begin{array}{llllllllllllllll}1 & 2 & 3 & 4 & 1 & 2 & 3 & 4 & 1 & 2 & 3 & 4 & 1 & 2 & 3 & 4\end{array}$ \\ BAND 1}

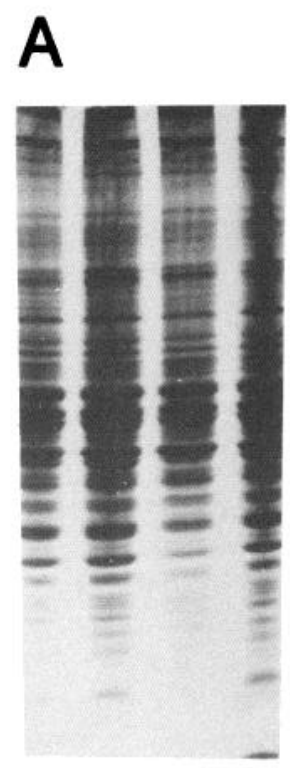

B

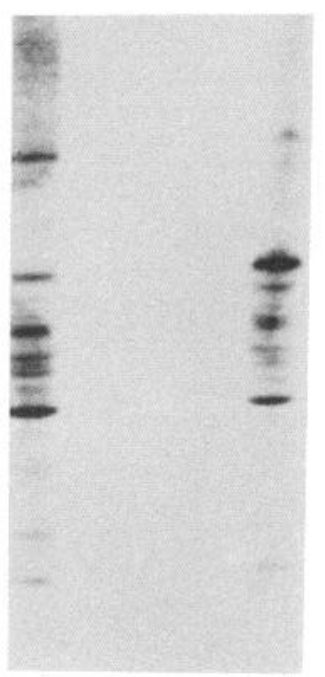

\section{2}

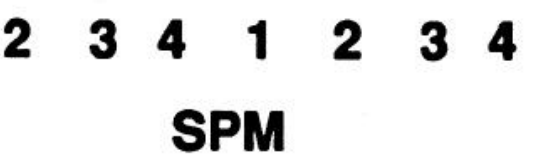

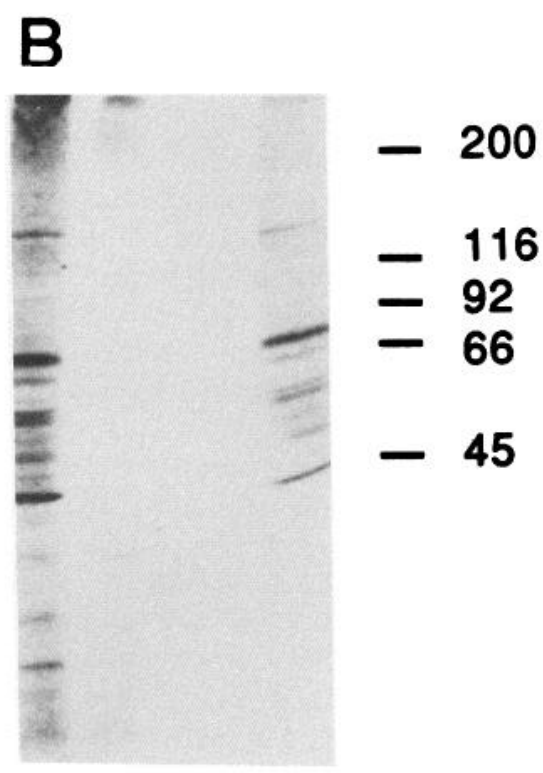

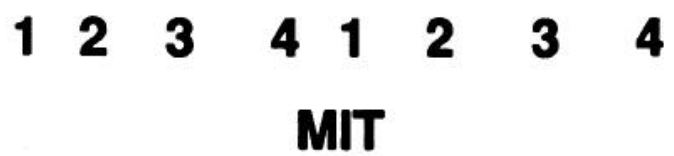

Figure 8. Subfractionation of membrane components of labeled synaptosomes. SDS-PAGE analysis of labeled proteins in synaptosomal subfractions after synaptosomal protein synthesis. Synaptosomes prepared from 21-d-old rat pups were labeled with ${ }^{35} \mathrm{~S}-\mathrm{methionine}$ and subfractionated as described in Materials and Methods. Approximately $5 \mu \mathrm{g}$ each of Band 1, Band 2, SPM, and the mitochondrial subfraction (MIT) were loaded on a 5-15\% gradient $4 \mathrm{~m}$ urea gel. Material from control (1), CYC-treated (2), CYC and CAP-treated (3), and CAP-treated (4) synaptosomes was used. The cpm in controls ranged from approximately 3000 in MIT to 2400 in Band 1. Left, Serva Coomassie Blue/ammonium sulfate-stained gel prepared as in Neuhoff et al. (1985). Right, Fluorograph (14 d exposure). The positions of molecular weight standards of the indicated molecular weight $(\times 1000 \mathrm{Da})$ are indicated on the right. 

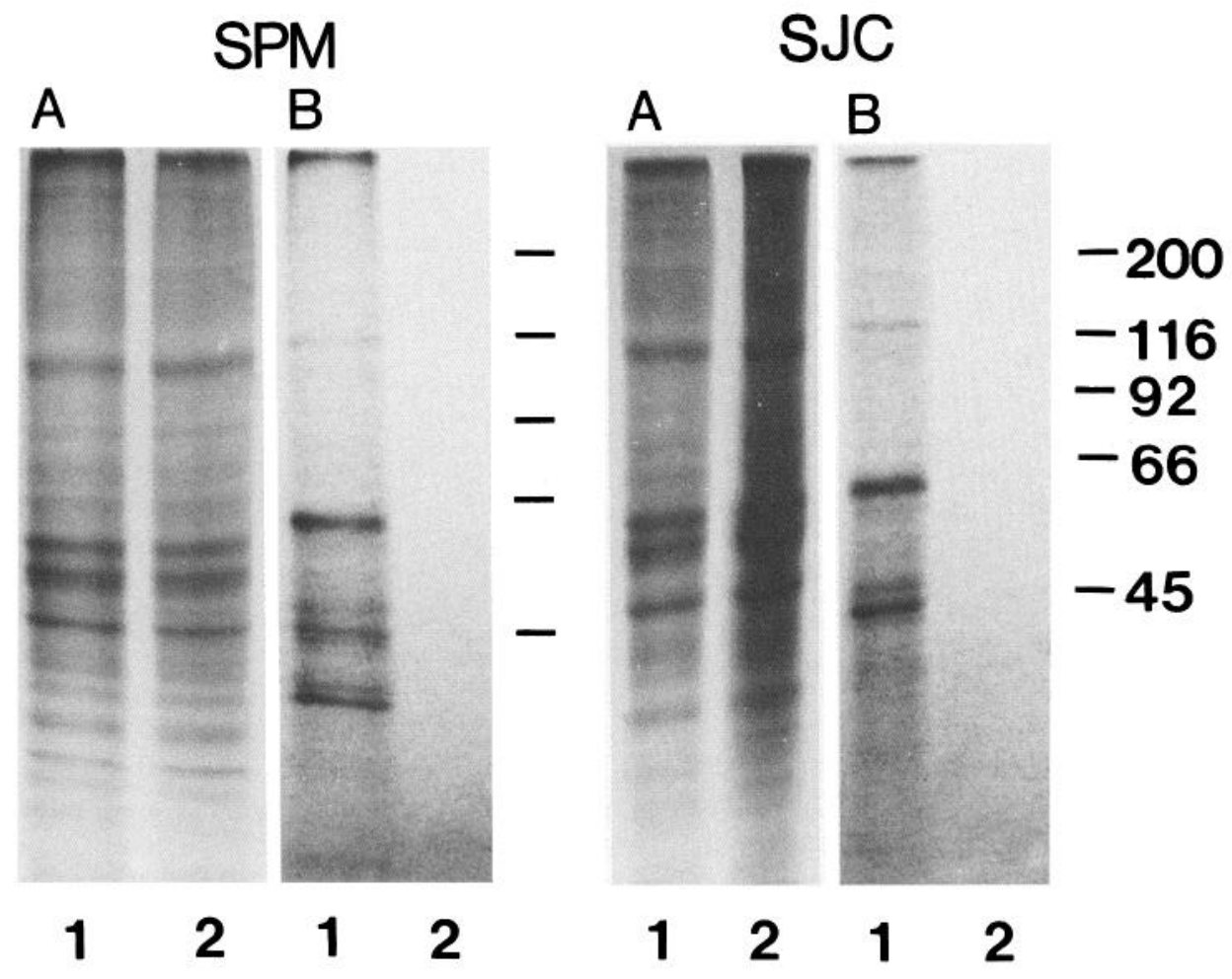

Figure 9. Gel analysis of adventitious binding of labeled soluble proteins. Two equal protein samples from a synaptosomal preparation from 22-d-old rats were incubated as in Materials and Methods, one with ${ }^{35} \mathrm{~S}$-methionine (labeled) and one without (unlabeled). After incorporation, the two samples were pelleted and subjected to osmotic shock. The labeled and unlabeled soluble protein released into the medium was collected from the supernatant after pelleting the membrane. The soluble protein from the labeled synaptosomes was added to the unlabeled membrane preparation, and the suspension was incubated for an additional $10 \mathrm{~min}$. The membrane pellet was then collected from the labeled and unlabeled preparations and subjected to the usual fractionation procedure. SDS-PAGE and fluorography was then carried out with $S P M$ and $S J C$ subfractions obtained from synaptosomal membranes that were: labeled $(I)$ and unlabeled, treated with labeled soluble proteins (2). Approximately $20 \mu \mathrm{g}$ of sample protein were loaded on $5-15 \%$ gradient gels containing urea. $A$, Serva Coomassie Blue R/ammonium sulfate-stained gel prepared as in Neuhoff et al. (1985). B, Fluorograph (11 d exposure). The positions of molecular weight standards of the indicated molecular weight $(x$ $1000 \mathrm{Da})$ are indicated on the right. "sticky" and therefore artefactually binds labeled protein released by homogenization. Matus et al. (1980) showed that some cytoskeletal proteins (neurofilament and glial fibrillary acidic protein) adhere selectively to the PSD during homogenization and throughout the isolation procedure. As a result, these proteins coisolate with PSDs although neither protein is thought to be a component of PSDs in intact tissue. Carlin et al. (1982) also demonstrated that tubulin accumulates in a time-dependent fashion in PSD preparations from postmortem tissue. It is unlikely that the labeled polypeptides in our SJC preparation are due to such adventitious binding since some polypeptides (at 38,42 , and $55 \mathrm{kDa}$ ) that usually appear in fluorographs of the SJC are seldom labeled in the soluble fraction, and one labeled polypeptide at $60 \mathrm{kDa}$ that is always seen in fluorographs of the $\mathrm{SJC}$ is not observed in fluorographs of the soluble fraction (e.g., compare soluble fraction polypeptides in Fig. 4 with SPM/SJClabeled polypeptides in Figs. 7-9). Furthermore, addition of labeled soluble protein to an unlabeled membrane preparation demonstrated minimal binding of labeled soluble proteins to the SPM and SJC, and none of the labeled bands evident in fluorographs of the control SPM and SJC were detectable in the cold preparation (Fig. 9).

Our results also provide further evidence about the nature of the protein synthetic systems present in synaptosomes. Early studies of synaptosomal protein synthesis evaluated the effects of different inhibitors on the incorporation (Autilio et al., 1968; Gordon and Deanin, 1968; Morgan and Austin, 1968) but did not subfractionate the various membrane components of the synaptosome. Thus, our results are the first to show that recently synthesized proteins are found in the SPM and SJC and therefore that eucaryotic ribosomal systems capable of synthesizing synaptic proteins are present in the synaptosomal fractions.

The gel analyses in our study are the first to characterize the synaptic polypeptides made in this system. Wedege et al. (1977) performed gel analyses of whole synaptosomes after incorporation of labeled amino acids, as did Irwin (1985), but the pattern of labeled polypeptides in the unfractionated synaptosome is complicated by the presence of labeled soluble proteins and mitochondrial proteins. These have been separately analyzed in our study.

\section{Nature of the labeled polypeptides}

Some of the labeled bands seen in fluorographs of our SPM and SJC preparations (at 45,55 , and $220 \mathrm{kDa}$ ) have apparent molecular weights that are similar to those of cytoskeletal proteins that have been detected at synaptic junctions (actin, tubulin, and MAP-2, respectively). Both actin and tubulin are thought to be present in PSDs based on biochemical and immunocytochemical data (Matus et al., 1975; Toh et al., 1976; Kelly and Cotman, 1977, 1978). MAP-2 has been detected in the PSD with EM immunohistochemistry (Cacares et al., 1984). The colocalizations we see would suggest that $\alpha$-tubulin, actin, and MAP-2 may be locally synthesized. However, in situ hybridization studies have shown that mRNA for at least one tubulin isotype ( $\beta$-tubulin) is not present in dendrites (Bruckenstein et al., 1990; Kleiman et al., 1990). This is also the case for the mRNA for $\beta$-actin (R. Kleiman, G. Banker, and O. Steward, unpublished observations). It is conceivable that the mRNAs 
for other isotypes of these proteins are present in dendrites and participate in local protein synthesis. The mRNA for MAP-2 has been detected in dendrites (Garner et al., 1988; Kleiman et al., 1990), making MAP-2 a good candidate for a locally synthesized synaptic polypeptide.

The mRNA for the $\alpha$-subunit of calcium/calmodulin-dependent kinase-2 (Ca/CaMK2) has been detected in neuropil areas rich in dendrites (Burgin et al., 1990). Ca/CaMK2 is a multimeric protein containing $52-\mathrm{kDa}(\alpha)$ and $60-\mathrm{kDa}(\beta)$ subunits and is a major protein component of the synaptic junction (Kennedy et al., 1983; Kelly et al., 1984; Kelly and Vernon, 1985). The $52 \mathrm{kDa}$ and $60 \mathrm{kDa}$ polypeptides are prominent in the Coomassie pattern in adult SJCs but less prominent in the immature SJC. (Kelly and Cotman, 1981; Kelly and Vernon, 1985). Interestingly, the mRNA for the $\beta$-subunit of the kinase does not appear to be present in dendrites (Burgin et al., 1990). These findings make the $52 \mathrm{kDa}$ subunit of the kinase an attractive candidate for a locally synthesized synaptic protein. There were several labeled bands in the 50-60 kDa region of the gels of our SPM and SJC preparations, and the most prominent labeled band was at $60 \mathrm{kDa}$. However, the more prominent labeled bands we see do not colocalize with the Coomassie-stained band we believe is the locus of the $\mathrm{Ca} / \mathrm{CaM}$ kinase $52 \mathrm{kDa}$ subunit. The prominent labeled band at $60 \mathrm{kDa}$ does not colocalize with any major Coomassie-stained band and is therefore unlikely to be the $60 \mathrm{kDa}$ subunit of the kinase. One interpretation of our results is that the $52 \mathrm{kDa}$ and $60 \mathrm{kDa}$ subunits of the kinase are not locally synthesized beneath synapses even though the mRNA for the $52 \mathrm{kDa}$ subunit is present in dendrites. However, our inability to demonstrate the newly synthesized $52 \mathrm{kDa}$ subunit of the kinase in this system could also be due to (1) the absence or low abundance of the mRNA in comparison to other mRNAs [some synaptosome preparations from adult rats have been shown to contain the message for the $52-\mathrm{kDa}$ subunit (Chicurel et al., 1990), which suggests that this possibility is unlikely]; (2) the inability to translate the message in the synaptosomal preparation; or (3) some property of the newly synthesized polypeptide that leads to its migration at a different apparent molecular weight than expected. Such anomolous migration could be due to a lack of normal posttranslational modification of the protein synthesized within synaptosomes. As a fourth possibility, it is also conceivable that the newly synthesized polypeptide is unable to partition from the subsynaptic cytoplasm into the postsynaptic specialization in this system. The $52 \mathrm{kDa}$ subunit of the $\mathrm{Ca} / \mathrm{CaMK} 2$ changes its association developmentally from a predominantly soluble compartment to a particulate one (Kelly and Vernon, 1985). During the developmental period in which we have studied local synaptic protein synthesis, the $\mathrm{Ca} / \mathrm{CaMK} 2$ is largely soluble.

Two prominent labeled bands in the SPM and SJC preparations, at $60 \mathrm{kDa}$ and $116 \mathrm{kDa}$, do not colocalize with major Coomassie-staining bands (Figs. 7-9). These bands were always scen in urca gels of the SJC but were less apparent in fluorographs of nonurea gels, where diffuse labeling was apparent at the top of the gel and in the stacking gel. A number of identified membrane glycoproteins (including receptor or channel polypeptides) have been reported to form very high molecular weight aggregates when boiled in SDS-containing buffers (like those used in our study) and then electrophoresed on nonurea gels (Wong et al., 1978; Rauh et al., 1986). These aggregates form a streak at the top of the gel similar to the ones we normally see in nonurea gels. These glycoproteins can, however, be clearly resolved by urea treatment (Rauh et al., 1986). While the phenomenon of aggregation in the presence of SDS and disaggregation in the presence of urea and SDS does not necessarily indicate a membrane glycoprotein, this characteristic coupled with the colocalization with polypeptides of low abundance and the enrichment in membrane and not in soluble fractions (see Fig. 4) suggests that these labeled bands may be glycoproteins. Some known synaptic glycoproteins are of these molecular weights (Beesely, 1989; Gurd, 1989). If any of the labeled polypeptides are indeed glycoproteins, an important question is how such locally synthesized proteins could be glycosylated.

\section{Conclusion}

The present paper provides new evidence supporting the hypothesis that the polyribosomes that are present beneath postsynaptic sites synthesize protein components of the postsynaptic junction. In synaptosomes, the possibility of intracellular transport from other cellular sources is eliminated, and one can be sure that any precursor incorporation observed reflects protein synthesis within a defined subcellular compartment. One must be concerned that the synthesis of particular proteins may be disrupted in the subcellular fractions and that the local synthesis seen in this system may not reflect all local synthetic systems present in the intact cell. Thus, it is still to be established whether the polyribosomes that are present in dendrites also synthesize other types of protein (e.g., cytoskeletal proteins that do not play a role in the synaptic junction, or soluble factors which may be released at individual contact sites). Finally, although the identities of the locally synthesized synaptic proteins are still unknown, the present study provides at least an initial characterization of their diversity and molecular weight characteristics.

\section{References}

Appel SH, Davis W, Scott S (1967) Brain polysomes: response to environmental stimulation. Science 157:836-838.

Autilio LA, Appel SH, Pettis P, Gambetti P (1968) Biochemical studies of synapses in vitro. 1. Protein synthesis. Biochemistry 7:26152622.

Beesely, PW (1989) Immunological approaches to the study of synaptic glycoproteins. Comp Biochem Physiol 93A:255-266.

Bradford MM (1976) A rapid and sensitive method for the quantitation of microgram quantities of proteins utilizing the principle of protein-dye binding. Anal Biochem 72:248-254.

Bruckenstein DA, Lein PJ, Higgins D, Fremeau RT Jr (1990) Distinct spatial localizations of mRNA in cultured sympathetic neurons. Neuron 5:809-819.

Burgin KE, Waxham MN, Rickling S, Westgate SA, Mobley WC, Kelly PT (1990) In situ hybridization histochemistry of $\mathrm{Ca} /$ calmodulin dependent protein kinase in developing rat brain. J Neurosci 10:17881798.

Cacares A, Binder LI, Payne MR, Bender P, Rebhun L, Steward O (1984) Differential subcellular localization of tubulin and the microtubule-associated protein MAP2 in brain tissue as revealed by immunocytochemistry with monoclonal hybridoma antibodies. J Neurosci 4:394-410.

Carlin RK, Grab DJ, Sickevitz P (1982) Postmortem accumulation of tubulin in postsynaptic density preparations. J Neurochem 38:94100.

Chicurel ME, Terrian DM, Potter H (1990) Subcellular localization of mRNA: isolation and characterization of mRNA from an enriched preparation of hippocampal dendritic spines. Soc Neurosci Abstr 16: $344,151.4$.

Cotman C, Taylor D (1971) Autoradiographic analysis of protein synthesis in synaptosomal fractions. Brain Res 29:366-372.

Cotman C, Taylor D (1972) Isolation and structural studies on synaptic complexes from rat brain. J Cell Biol 55:696-711.

Deanin GG, Gordon MW (1973) Chloramphenicol- and cyclohexi- 
mide-sensitive protein synthetic systems in brain mitochondrial and nerve-ending preparations. J Neurochem 20:55-68.

Ennis HL, Lubin M (1964) Cycloheximide: aspects of inhibition of protein synthesis in mammalian cells. Science 146:1474-1476.

Gambetti P, Autilio-Gambetti LA, Gonatas NK, Shafer B (1972) Protein synthesis in synaptosomal fractions: an ultrastructural radioautographic study. J Cell Biol 52:526-535.

Garner CC, Tucker RP, Matus A (1988) Selective localization of messenger RNA for cytoskeletal protein MAP2 in dendrites. Nature 336: 674-677.

Gordon MW, Deanin GG (1968) Protein synthesis by isolated rat brain mitochondria and synaptosomes. J Biol Chem 243:4222-4226.

Gurd JW (1989) Glycoproteins of the synapse. In: Neurobiology of the glycoconjugates (Margolis RU, Margolis RK, eds), pp 219-242. New York: Plenum.

Irwin CC (1985) Comparison of protein synthesis in mitochondria, synaptosomes and intact brain cells. J Neurochem 44:433-438.

Kelly PT, Cotman CW (1977) Identification of glycoproteins and proteins at synapses in the central nervous system. J Biol Chem 252: 786-793.

Kelly PT, Cotman CW (1978) Synaptic proteins: characterization of tubulin and actin and identification of a distinct postsynaptic density polypeptide. J Cell Biol 79:173-183.

Kelly PT, Cotman CW (1981) Developmental changes in morphology and molecular composition of isolated synaptic junctional structures. Brain Res 206:251-271.

Kelly PT, Montgomery PR (1982) Subcellular localization of the 52,000 molecular weight major postsynaptic density protein. Brain Res 233 : 265-286.

Kelly PT, Vernon P (1985) Changes in the subcellular distribution of calmodulin-kinase II during brain development. Dev Brain Res 18: 211-224.

Kelly PT, McGuinness TL, Greengard P (1984) Evidence that the major postsynaptic density protein is a component of a $\mathrm{Ca}^{++} / \mathrm{cal}-$ modulin-dependent protein kinase. Proc Natl Acad Sci USA 81:945949.

Kennedy MB, Bennet MK, Frondu NF (1983) Biochemical and immunochemical evidence that the major postsynaptic density protein is a subunit of a calmodulin dependant protein kinase. Proc Natl Acad Sci USA 80:7357-7361.

Kleiman R, Banker G, Steward O (1990) Differential subcellular localization of particular mRNAs in hippocampal neurons in culture. Neuron 5:821-830.

Laemmli UK (1970) Cleavage of structural proteins during the assembly of the head of bacteriophage T4. Nature 277:680-685.

Matus AI, Walters BB, Mughal S (1975) Immunohistochemical demonstration of tubulin associated with microtubules and synaptic junctions in mammalian brain. $\mathrm{J}$ Neurocytol 4:733-744.

Matus A, Pehling G, Ackerman M, Meeder J (1980) Brain postsynaptic densities: their relationship to glial and neuronal filaments. J Cell Biol 87:346-359

Morgan IG (1970) Protein synthesis in brain mitochondrial and synaptosomal preparations. FEBS Lett 10:273-275.
Morgan IG, Austin L (1968) Synaptosomal protcin synthcsis in a ccllfree system. J Neurochem 15:41-51.

Neuhoff V, Stamm R, Eibl H (1985) Clear background and highly sensitive protein staining with Coomassie Blue dyes in polyacrylamide gels: a systematic analysis. Electrophoresis 6:427-448.

Palacios-Pru EL, Palacios L, Mendoza RV (1981) Synaptogenetic mechanisms during chick cerebellar cortex development. J Submicrosc Cytol 13:145-167.

Palacios-Pru EL, Miranda-Contreras L, Mendoza RV, Zambrano E (1988) Dendritic RNA and postsynaptic density formation in chick cerebellar synaptogenesis. Neuroscience 24:111-118.

Rao A, Torre ER, Steward O (1988) Evidence that proteins of the synaptic membrane are synthesized locally within dendrites: studies of synaptosomal protein synthesis. Soc Neurosci Abstr 14:234.10.

Rauh JJ, Lambert MP, Cho NJ, Chin H, Klein WL (1986) Glycoprotein properties of muscarinic acetylcholine receptors from bovine cerebral cortex. J Neurochem 46:23-32.

Smith PK, Krohn RI, Hermanson AK, Mallia AK, Gartner FH, Provenzano MD, Fujimoto EK, Goeke NM, Olson BJ, Klenk DC (1985) Measurement of protein using bicinchoninic acid. Anal Biochem 150: $76-85$.

Steward O (1983) Alterations in polyribosomes associated with dendritic spines during the reinnervation of the dentate gyrus of the adult rat. J Neurosci 3:177-188.

Steward O, Falk PM (1986) Protein synthetic machinery at postsynaptic sites during synaptogenesis: a quantitative study of the association between polyribosomes and developing synapses. J Neurosci 6: $412-423$.

Steward O, Levy WB (1982) Preferential localization of polyribosomes under the base of dendritic spines in granule cells of the dentate gyrus. J Neurosci 2:248-291.

Steward O, Davis L, Dotti C, Phillips LL, Kao A, Banker G (1988) Protein synthesis and processing in cytoplasmic microdomains beneath postsynaptic sites on CNS neurons: a mechanism for establishing and maintaining a mosaic postsynaptic receptive surface. Mol Neurobiol 2:227-261.

Toh BH, Gallichio HA, Jeffrey PI, I ivett BG, Muller HK, Cauchi MN, Clarke FM (1976) Anti-actin stains synapses. Nature 264:648-650.

Verity MA (1972) Cation modulation of synaptosomal respiration. J Neurochem 19:1305-1317.

Verity MA, Brown WJ, Cheung M (1980) Isolation of ribosome containing synaptosome subpopulation with active in vitro protein synthesis. J Neurosci Res 5:143-153.

Wedege E, Luqmani Y, Bradford HF (1977) Stimulated incorporation of amino acids into proteins of synaptosomal fractions induced by depolarizing treatments. J Neurochem 29:527-537.

Wheeldon LW, Lehninger AL (1966) Energy-linked synthesis and decay of membrane protein in isolated rat liver mitochondria. Biochemistry 5:3533-3545.

Wong MM, Robertson NP, Horwitz J (1978) Heat induced aggregation of the sodium dodecyl sulfate-solubulized main intrinsic polypeptide isolated from bovine lens plasma membrane. Biochem Biophys Res Commun 84:158-165. 